\title{
Rethinking the Ethics of John
}

"Implicit Ethics« in the Johannine Writings. Kontexte und Normen neutestamentlicher Ethik / Contexts and Norms of New Testament Ethics. Volume III

\author{
Ed. by Jan G. van der Watt and Ruben Zimmermann
}

[Die Ethik des Johannes - neu bedacht. Die »implizite Ethik« in johanneischen Schriften.]

Veröffentlicht auf Englisch.

Gibt es eine »Ethik im Johannesevangelium«? Sowohl innerhalb der Forschungen zur Ethik des Neuen Testaments wie auch zu den johanneischen Schriften wurde diese Frage in der Regel negiert oder auf die binnenorientierte Konventikelethik einer Sekte reduziert.

Rethinking the Ethics of John

Edited by JAN G. VAN DER WATT and RUBEN ZIMMERMANN

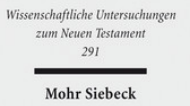

2012. XI, 395 Seiten. WUNT I 291

ISBN 978-3-16-152104-1 DOI 10.1628/978-3-16-152104-1 eBook PDF 134,00€ ISBN 978-3-16-151830-0 Leinen $134,00 €$
Die Beiträge der vorliegenden Studie machen deutlich, dass die frühere Forschung von Methoden und Begriffen geleitet war die weder der antiken Ethik noch den johanneischen Schriften gerecht wird. Die Handlungsreflexion und Normendiskussion wird im Johannesevangelium nicht argumentativ und in Gestalt direkter Imperative vollzogen, gleichwohl stehen Handeln, Werke und Leben ganz im Zentrum des vierten Evangeliums.

Die Beiträge des Bandes nehmen traditionsgeschichtliche, sprachliche und rezeptionsästhetische Aspekte in den Blick und zeigen in ihrer Vielfalt, wie reichhaltig die »implizite Ethik« der johanneischen Schriften ist.

Die Untersuchung ist ebenso eng mit den ethischen Forschungen an der Radboud Universität wie mit dem Mainzer Forschungszentrum »Ethik in Antike und Christentum« verbunden. Sie stellt einen weiteren Beitrag zu den »Kontexten und Normen der frühchristlichen Ethik« dar.

\section{Inhaltsübersicht}

Preface

Introduction: Overview of Research

Michael Labahn : »It's Only Love« - Is That All? Limits and Potentials of Johannine »Ethic« - A Critical Evaluation of Research Ruben Zimmermann: Is there Ethics in the Gospel of John? Challenging an outdated consensus

Possible backgrounds for Johannine ethics

Andrew T. Glicksman : Beyond Sophia: The Sapiential Portrayal of Jesus in the Fourth Gospel and Its Ethical Implications for the Johannine Community - Erik Eynike/: The Qumran background of Johannine Ethics - Volker Rabens: Johannine Perspectives on Ethical Enabling in the Context of Stoic and Philonic Ethics

Ethics in the Gospel according to John

William R.G. Loader: The Law and Ethics in John's Gospel - Karl Weyer-Menkhoff: The Response of Jesus. Ethics in John by considering Scripture as Work of God - Jan G. van der Watt: Ethics of/and the opponents of Jesus in John's Gospel - Christos Karakolis : Semeia Conveying Ethics in the Gospel according to John - Mira Stare : Ethics of life in the Gospel of John - Hermut Löhr: "Epyov as an Element of Moral Language in John - Chrys C. Caragounis : »Abide in me«. The New Mode of Relationship Between Jesus and His Followers as a Basis for Christian Ethics (John 15) - Glen Lund: The Joys and Dangers of Ethics in John's Gospel - Paul N. Anderson: Discernment-Oriented Leadership in the Johannine Situation - biding in the Truth versus Lesser Alternatives

Ethics in 1 John

Udo Schnelle: Ethical Theology in 1 John - Jeffrey E. Brickle: Transacting Virtue within a Disrupted Community: The Negotiation of Ethics in the First Epistle of John - Tom Thatcher: Cain the Jew the AntiChrist: Collective Memory and the Johannine Ethic of Loving and Hating

Jan G. van der Watt Born 1952; emeritus professor of the University of Pretoria (South Africa) and Radboud University Nijmegen (Netherlands) as well as research associate University of the Free State (South Africa).

Ruben Zimmermann Born 1968; 1999 Dr. theol. from the University of Heidelberg; 2003 Habilitation from the LudwigMaximilians-University München; currently Professor of New Testament and Ethics at the Johannes Gutenberg-University in Mainz, Germany and research associate at the Department of Old and New Testament Studies of the University of the Free State, Bloemfontein, South Africa. https://orcid.org/0000-0002-1620-4396

Jetzt bestellen:

https://mohrsiebeck.com/buch/rethinking-the-ethics-of-john-9783161521041?no_cache=1

order@mohrsiebeck.com

Telefon: +49 (0)7071-923-17

Telefax: $+49(0) 7071-51104$ 